\title{
Generational Differences In The Workplace: Personal Values, Behaviors, And Popular Beliefs
}

Jane Whitney Gibson, Nova Southeastern University, USA

Regina A. Greenwood, Nova Southeastern University, USA

Edward F. Murphy, Jr., Embry Riddle Aeronautical University, USA

\begin{abstract}
This paper uses popular and academic literature to describe the distinguishing characteristics that differentiate Baby Boomers, Gen X and Gen Y. The authors then further examine these differences by comparing the results of a survey of 5,057 members of these cohorts, using the Rokeach Value Survey, to the previously generated profiles. Both terminal and instrumental values of the respondents were analyzed. Results generally confirm the popular profiles and suggest that managers should take these profiles into consideration when leading, motivating, and communicating with employees belonging to these generations.
\end{abstract}

Keywords: generations, values, Rokeach, Baby Boomers

\section{INTRODUCTION}

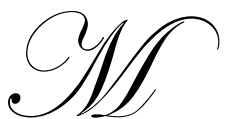

uch attention has been given in recent years to the intergenerational conflict in the workplace caused by diversity in values related to age. While different beginning and ending dates are attributed to the Baby Boomer, Generation X and Generation Y cohorts, the popular and academic literature agree on a core group of values found among these workers. These values in turn lead to speculation about what these workers want occupationally and how to motivate them to be both committed and productive organizational members.

Baby Boomers, for example, are thought to be competitive and loyal workaholics who value individual freedom and dedication to task. Generation X, on the other hand, crave more of a balance between work and family, are more cynical, informal, fun-loving and independent. Generation $\mathrm{Y}$ is characterized as socially sensitive, optimistic, ambitious, curious, technologically adept, and easily bored. This paper will build a profile of generational values based on both popular and academic articles.

The current study then looks at these popularly accepted beliefs about generational values and compares them to results of a study using the Rokeach Value Survey. Do the personal values of the three generations as reported by members of those cohorts reflect the popular concepts? Specifically, the top ten instrumental and terminal values as reported by the survey respondents are analyzed in terms of their "fit" with the previously mentioned model. If there is a degree of congruence, what would it mean for managers who lead these three generations on a daily basis? The paper will conclude with a discussion of implications for managers. We begin by suggesting a central research question and then by proposing the generational profiles based on the literature.

\section{THE RESEARCH QUESTION}

This study examines the commonly-accepted profile of characteristics of Generation X, Y, and Baby Boomers and uses the Rokeach Value Survey for an empirical study of values among representatives of each 
generation in the U. S. The research question is: Will an empirical study of values support descriptions of the generations found in the literature?

\section{GENERATIONAL PROFILES}

Generational research dates back to Mannheim (1953) who defined generations as a group of people born and raised in the same general chronological, social and historical context. A discussion of generational differences often looks at values held by each age cohort. Morris Massey (2005) raised awareness of how these differences play out in the workplace through a series of popular films beginning with "What You Are is Where You Were When" which implied that one's values depended on where you were during the value formation years (0-20 years) and what you experienced during that time. While there is considerable disagreement as to beginning and closing years for each generation, the following dates are reflected in the current study. The Baby Boomer generation is defined as 1946-1964 as suggested by Strauss \& Howe (1997) and Egri \& Ralston (2004). The same sources used 19651979 as the years for Generation X, and so do we. Finally, this study uses the dates 1980 to present for Generation $\mathrm{Y}$ as per Eisner (2005) and Murphy et. al. (2006).

\section{The Baby Boomers}

The Baby Boomer generation, approximately 85 million strong, is the largest cohort currently in the workplace (Trunk, 2007) and the one with the most power by virtue of their high numbers in leadership positions. Baby Boomers are reputed to be loyal and competitive workaholics (Crampton \& Hodge, 2007) whose serious and dedicated attitude toward work has been influenced by the Vietnam War and the economic prosperity following World War II (Patota, Schwartz \& Schwartz, 2007). This same prosperity may account for their reputed selfabsorption (Weil, 2008) and a feeling of entitlement (Lyons, 2005). This indulgence was expressed by many young Baby Boomers who grew up in the 60s by the mantra of sex, drugs, and rock \& roll. (Brandt, 2008). Boomers experienced much social change in their early years and therefore embrace change and growth (Crampton \& Hodge, 2007). In addition, Massey (1979) says the Boomers value success, teamwork, inclusion and rule-challenging. Likewise they have proven their determination to fight for a cause. (National Oceanographic...)

\section{Generation X}

Many Generation X adults grew up in dual worker families which gave rise to the new term, "latch-key kids." Thus, they are self-reliant, fun-loving, and independent (Lyons, 2005). They are also less loyal than the Boomers having witnessed high numbers of divorces and corporate downsizing. (Crampton \& Hodge, 2007). Unable as a generation to enjoy the career success of their predecessors, the Generation X'ers are more concerned with career options, balance of work and non-work lives, and express cynicism toward Corporate America (Crampton \& Hodge, 2007). At work, they are computer literate and want a fun environment (Patota, Schwartz \& Schwartz, 2007) but they are far more mobile than the Baby Boomers, moving from job to job to improve their careers (Johnson \& Lopes, 2008).

Generation Xers experienced economic uncertainties, the beginning of the AIDS epidemic and the end of the Cold War, as well as corporate and government scandals, all feeding into their distrust of authority. (Johnson \& Lopes, 2008). Instead, they rely on personal entrepreneurial effort, independence \& creativity (National Oceanographic...). At work, they demand fulfilling work (Merrill, 2008) but may be seen by their Baby Boomer bosses as "slackers" who lack loyalty. (Rottier, 2001).

\section{Generation Y}

Generation Y saw the insecurities of the Cold War replaced by Columbine, 9/11, and celebrity scandals. They were raised with MTV, cell phones, IPods, and computer games and are totally at home with instant communication and social networking. This digital generation is optimistic, realistic, globally aware, and inclusive by nature (McNamara, 2005). Less indulged than the X generation, the Millennials accept diversity and different types of families (Alch, 2008); they are civic-minded and prone to volunteerism (Leyden, Teixeira \& Greenberg, 
2007). Like the generation before them, they value work/family balance and independence (Yeaton, 2008) but they are also curious, questioning (Kehril \& Sapp, 2006) and results-oriented (Streeter, 2007).

In the workplace, Millennials can try the patience of their Baby Boomer bosses and their Gen X colleagues. Their entrepreneurial, answer-seeking behaviors coupled with their sense of personal responsibility and need for feedback (Martin, 2005) can be diminished by their dissatisfaction with entry-level jobs and their tendency to change jobs frequently (Wallace, 2001). Millennials want a say in how they do their work; they are collaborative (Alch, 2008) and work well within the modern empowered workplace as long as there are enough challenges and opportunities to keep them interested (Martin, 2005).

Table 1: Generational Descriptors

\begin{tabular}{|c|c|c|}
\hline Baby Boomers & Generation X & Generation Y \\
\hline Sandwich generation & Latch-key kids & Netters \\
\hline Company loyalty & Lack of loyalty & Civic-minded \\
\hline Idealistic & Reactive & Self-centered \\
\hline Self-absorbed & Self-reliant & Multi-taskers \\
\hline Workaholic & Work/life balance & Tech experts \\
\hline Tech conservatives & Computer savvy & Many family forms \\
\hline Entitled & Cynical/skeptical & Crave feedback \\
\hline Traditional family & Divorced family & Serial Entrepreneurs \\
\hline Wary of authority & Independent & Volunteers \\
\hline Competitive & Entrepreneurial & Distance learning \\
\hline Materialistic & Fun-loving & Crave challenge \\
\hline Training & Life-long learning & High maintenance \\
\hline Comfortable with change & Creative & Collaborative \\
\hline Optimistic & Want fulfilling work & Career options \\
\hline
\end{tabular}

Table 1 shows a list of descriptors that may be drawn of each generation from the academic and popular articles consulted above.

\section{METHOD}

The Rokeach Value Survey (RVS) has been used since 1968 to study instrumental and terminal values of individuals in a variety of national, international, multinational, and professional settings. Terminal values according to Rokeach measure "the ultimate end goals of existence, such as wisdom, equality peace, or family security," while instrumental values measure "the behavioral means for achieving such end-goals, for instance, the importance of being honest, ambitious, forgiving, or logical.” (Rokeach \& Ball-Rokeach, 1989, p. 776).

The RVS requires respondents to rank order both instrumental and terminal values in terms of their relative importance to the respondents. Between 2003 and 2008 working adults were surveyed using the RVS. From that initiative, 5,057 surveys were found to be usable for this study and analyzed. Of these, 1,464 were classified as Baby Boomers, 1,440 belonged to Generation Y and 2,153 were Millennials.

\section{FINDINGS}

Table 2 shows the ranking of terminal values by generation and Table 3 shows the instrumental values by generation as developed by this study. Note that the top 10 are in bold for easy reference. Our examination will focus on these top 10 values since they were designated the most important values by our respondents

An examination of Table 2 shows a good deal of congruence between the generational value profiles described above and in Table 1 and the value profiles of Table 2. "Health" and "family security" ranked \# 1 and 2 for all three generations. It is logical that" health" edged out "family security" for the older generation who may face 
more health issues and fewer family responsibilities than the younger generations. It is notable that "freedom" (independence and free choice) ranked as relatively more important to the Generation X and Generation $\mathrm{Y}$ respondents just as their popular profiles would suggest. Likewise, the high ranking of "true friendship" (close companionship) by Gen Y supports the networking, socially-conscious profile of the Millennials. Also, Gen Y, with its high need for "accomplishment" (making a lasting contribution) supports their craving for challenge and civicmindedness. Additionally, just as we would expect, Gen X's value for "pleasure" (an enjoyable, leisurely life) was higher than the other generations. One of the most notable value differences is Generation X's relatively high value on "inner harmony" (freedom from inner conflict) as compared especially to the Gen Y respondents who ranked "inner harmony" near the bottom of the list. Managers could conclude from this that while Gen X will struggle to avoid such conflict, Gen Y will be little affected by it.

Table 2: Ranking of Terminal Values by Generation

\begin{tabular}{|c|c|c|c|}
\hline $\begin{array}{l}\text { Terminal Value } \\
\text { Ranking }\end{array}$ & Baby Boomer & Generation $X$ & Generation $Y$ \\
\hline $\begin{array}{c}\text { \# } 1 \text { (most } \\
\text { important) }\end{array}$ & Health & Family security & Family security \\
\hline \# 2 & Family security & Health & Health \\
\hline$\# 3$ & Self-respect & Freedom & Freedom \\
\hline$\# 4$ & A comfortable life & A comfortable life & True friendship \\
\hline$\# 5$ & Freedom & Inner harmony & Self-respect \\
\hline$\# 6$ & Wisdom & Self-respect & A comfortable life \\
\hline$\# 7$ & True friendship & True friendship & A sense of accomplishment \\
\hline$\# 8$ & Salvation & Wisdom & Wisdom \\
\hline$\# 9$ & Inner harmony & Mature love & Mature love \\
\hline$\# 10$ & A sense of accomplishment & Pleasure & Salvation \\
\hline$\# 11$ & Mature love & A sense of accomplishment & An exciting life \\
\hline$\# 12$ & An exciting life & Salvation & Equality \\
\hline$\# 13$ & Pleasure & An exciting life & Pleasure \\
\hline$\# 14$ & A word at peace & Equality & National security \\
\hline$\# 15$ & National security & A world at peace & A world at peace \\
\hline$\# 16$ & Equality & National security & Inner harmony \\
\hline$\# 17$ & A word of beauty & Social recognition & Social recognition \\
\hline$\# 18$ & Social recognition & A world of beauty & A world of beauty \\
\hline
\end{tabular}

Table 3: Ranking of Instrumental Values by Generation

\begin{tabular}{|c|c|c|c|}
\hline $\begin{array}{l}\text { Terminal Value } \\
\text { Ranking }\end{array}$ & $\begin{array}{c}\text { Baby Boomer } \\
1946-1964\end{array}$ & $\begin{array}{c}\text { Generation X } \\
1965-1979\end{array}$ & $\begin{array}{l}\text { Generation } Y \\
\text { 1980-present }\end{array}$ \\
\hline $\begin{array}{c}\text { \# } 1 \text { (most } \\
\text { important) }\end{array}$ & Honest & Honest & Honest \\
\hline \# 2 & Responsible & Responsible & Responsible \\
\hline$\# 3$ & Loyal & Capable & Loving \\
\hline$\# 4$ & Capable & Loyal & Independent \\
\hline$\# 5$ & Independent & Loving & Ambitious \\
\hline$\# 6$ & Loving & Courageous & Loyal \\
\hline$\# 7$ & Ambitious & Logical & Broadminded \\
\hline$\# 8$ & Logical & Broadminded & Capable \\
\hline$\# 9$ & Forgiving & Independent & Self-Controlled \\
\hline$\# 10$ & Self-controlled & Helpful & Intellectual \\
\hline$\# 11$ & Intellectual & Ambitious & Helpful \\
\hline$\# 12$ & Courageous & Intellectual & Logical \\
\hline$\# 13$ & Helpful & Self-controlled & Courageous \\
\hline$\# 14$ & Polite & Forgiving & Clean \\
\hline$\# 15$ & Broadminded & Polite & Forgiving \\
\hline$\# 16$ & Clean & Clean & Polite \\
\hline$\# 17$ & Imaginative & Imaginative & Obedient \\
\hline$\# 18$ & Obedient & Obedient & Imaginative \\
\hline
\end{tabular}


Table 3 shows similar congruence between the value profile described above and the results of our survey. Interestingly, "honest" and "responsible" were the \# 1 and \#2 means-to-an-end described by each of the three cohorts. There are, however, some interesting points of comparison. Gen Y ranked "independence" higher than the Baby Boomers and much higher than Gen $\mathrm{X}$ who is known for their self-reliance. This may be a result of the fact that Gen X, by virtue of their upbringing, has been independent from an early age while Gen Y aspires to this degree of self-sufficiency. Likewise, Gen Y respondents put a higher priority on "ambition" than the other two groups. It may be argued that the Baby Boomers translate "ambition" as hard-working while Gen Y defines this same instrumental value as aspiring which would support each of their profiles. Interestingly, the Baby Boomer respondents ranked "broadminded" (open mindedness) very low while the same value was in the top eight for the other generations. This could give evidence to the reputed self-absorption of the Baby Boomers. On the other hand, only the Baby Boomers ranked "forgiving" as a top 10 value. This may well tie in with their company loyalty in the face of downsizing and corporate scandal. Likewise the fact that Gen X did not rank "self-controlled" (restrained and self-disciplined) among their top 10 values seems to reinforce their priority for having fun. More telling is the relatively low ranking of "loyalty" for Gen $\mathrm{Y}$ who is known for job-hopping and quick boredom if career opportunities are not immediately apparent. The one big surprise in Table 3 is the fact that the Baby Boomers and Gen X ranked "capable" (competent, effective) as a considerably higher value than Gen Y who are reputed to be results-oriented. The fact that Gen X ranked "capable" higher than the other two cohorts may be a result of their self-reliance and independence rather than any goal-orientation.

\section{IMPLICATIONS FOR MANAGERS}

Among the many challenges facing managers today is effectively dealing with a diverse workforce. Such diversity is not limited to gender, religious, ethnic, and racial backgrounds but also relates to the various generational values found in the workplace today. This study has confirmed that there are gross differences among the Baby Boomers, Generation X and Generation Y, but the reader should be cautioned against overgeneralizing or stereotyping any given individual by virtue of his/her membership in a particular generational cohort. It should be helpful, however, to be more sensitive to these gross generational differences in order to bridge what is commonly called the generation gap. Just as cultural sensitivity to other diverse factors is important to effective management, so too is an appreciation for the differences that exist among your workers because of their age-related value systems.

The Baby Boomer generation is found in senior and high-level positions throughout the private and public sectors. This huge cohort of individuals is characterized by hard work, resistance to authority, and a feeling of having earned the right to be in charge. Managers can likely motivate them with money and overtime, recognize them with praise and position, and expect them to be loyal. Unlike the generation before them, they embrace change and will champion a good cause. As these Baby Boomers retire from the workforce, they will be replaced by Gen $\mathrm{X}$.

Generation X, however, reflects the independence and self-reliance they earned as children and tend to be suspicious and cynical. They value family-work balance more than the other two generations and are not particularly loyal to their employer because they don't expect their employer to be loyal to them. Managers should try to make work meaningful and fun for this cohort and understand their skepticism for what it is: a reflection of their honest observations about the relationship between employer and employee.

Generation Y are the children of the Boomers and, as such, elicit the same incongruity of values that one expects between parents and children. The Millennials personify all the tech savvy, social networking, and constant connectedness that drives Boomers crazy and they bring to the workplace their need for instant gratification. Managers should try to make work exciting and relevant for this group, being careful to show them verifiable career opportunities if they exist. Where Boomers will do their job and like to be left alone, Gen Y wants attention and feedback. 


\section{CONCLUSION}

The authors began with a research question asking if an empirical study of values would support descriptions of the Baby Boomer, Gen X and Gen Y characteristics found in the literature. Responses from over 5,000 working adults using the Rokeach Value Survey confirmed that the generational profiles shown in both public and academic literature are accurate and therefore useful to managers in understanding and bridging the generation gap caused by these differences. An anecdote from one author's recent past might serve as an example.

When the author was presenting a paper on fun as an effective workplace strategy at a conference several years ago (Jeffcoat \& Gibson, 2006), two men presumably in their mid to late 50s argued vociferously that work "should not be fun." These Baby Boomers were just as serious in their outlook as the Gen X attendees who jumped to the author's defense and a heated argument ensued. The lesson for management is to expect these arguments and realize that not everyone will agree on the look and feel of the workplace. The challenge is to provide enough motivational stimulation and communicate in various modalities in order to reach all your employees and not just the ones who agree in principle with your values and beliefs.

\section{AUTHOR INFORMATION}

Jane Whitney Gibson, Professor of Management for Nova Southeastern University teaches management, leadership, human resource management, and organizational behavior at the graduate and undergraduate levels in both traditional and online formats. Gibson is the Editor of The Journal of Applied Management and Entrepreneurship and an editorial board member of several management journals. She is active in the Academy of Management, the SAM Advanced Management Society and the Southern Management Association and has written books and articles in her areas of academic interest.

Edward F. Murphy, Jr., Adjunct Professor of Business and Management for Embry Riddle Aeronautical University teaches Bachelor's Degree and Master of Business Administration courses throughout California. He is a retired United States Air Force officer and serves as an education and strategic planning consultant. Dr. Murphy's research interests are in strategic planning, organizational and societal culture, socialization, cross-cultural similarities and differences, sex roles, gender roles, values, aviation human factors and situational leadership.

Regina A. Greenwood, Professor of Business and Management at Nova Southeastern University teaches management, business strategy, and management history courses at the graduate and undergraduate levels. Dr. Greenwood is also the co-Historian and co-Archivist for the Academy of Management. She has published numerous research papers in her areas of interest: management history, strategy, cross-cultural factors, and lean management.

\section{REFERENCES}

1. Alch, M. L. (June 2008). Get ready for a new type of worker in the workplace: the net generation. Supervision 69(6), 18-21.

2. Brandt, J. R. (June 2008). Talkin' bout my generation. Retrieved July 22, 2009 from http://www.industryweek.com.

3. Crampton, S. M. and Hodge, J. W. (2007). Generations in the workplace: Understanding age diversity. The Business Review, Cambridge, 9(1), pp 16-23.

4. Egri, C. and Ralston, D. (2004). Generation cohorts and personal values: A comparison of China and the US, Organization Science, 15, pp. 210-220.

5. $\quad$ Eisner, S. P. (Autumn, 2005). Managing generation Y. SAM Advanced Management Journal, 70(4), 4 (4 pages)

6. Jeff coat, K. and Gibson, J. W. (February, 2006). Fun as Serious Business: Creating a Fun Work Environment as an Effective Business Strategy, Journal of Business and Economic Research, 4, (2).

7. Johnson, J. A. and Lopes, J. (2008). The intergenerational workforce revisited, Organizational Development Journal, 26, (1), pp. 31 - 37.

8. Kehrli, S. and Sopp, T. (2006). Managing generation Y. HRMagazine, 51(5), pp. 113 (4 pages) 
9. Leyden, P., Teixeira, R. and Greenberg, E. (2007). The progressive politics of the millennial generation. New Politics Institute. Retrieved May 8, 2008 from http://www.newpolitics.net/node/360?full report=1

10. Lyons, S. (November 2005). Are gender differences in basic human values a generational phenomenon? Sex Roles: A Journal of Research. Retrieved May 13, 2008 from http://wwwfindarticles.com/p/articles/mi_m2294/is_9-10_53/ai_n16084047/print

11. Mannheim, K. (1953). Essays on sociology and social psychology. New York: Oxford University Press: NY

12. Martin, C. A. (2005). From high maintenance to high productivity: What managers need to know about Generation Y. Industrial and Commercial Training, 37(1), 39-44.

13. Massey, M. (1979). The People Puzzle. Brady, NY.

14. Massey, M. (2005). What you are is where you were when-again! Enterprise Media, Cambridge, MA.

15. McNamara, S. A. (June, 2005). Incorporating generational diversity. AORN Journal. Retrieved May 20, 2008 from http://findarticles.com/p/articles/mi_mOFSL/is_6_81/ai_n15394405

16. Merrill, D. (May 2008). Boomers pass the workplace torch. The Lane Report, 23(5) p. 34+.

17. Murphy, E. F. Jr., Greenwood, R., Ruiz-Gutierrez, J., Manyak, T. G., Mujtaba, B. and Uy, A. (August, 2006). Generational value changes: Their history and a cross-cultural empirical test, Paper presented at the Academy of Management Meeting, Atlanta, Georgia.

18. National Oceanographic and Atmospheric Association of Diversity. Tips to improve interaction among the generations: Traditionalists, Boomers, X'ers and Nexters. Retrieved May 20, 3008 from http://www.honolulu.hawaii.edu/intranet/committees/FacDevCom/guidebk/teachtip/interencom

19. Patota, N., Schwartz, D. and Schwartz, T. (2007). Leveraging generational differences for productivity gains. Journal of American Academy of Business, Cambridge, 11(2), pp. 1-11.

20. Rokeach, M. and Ball-Rokeach, S. J. (May, 1989) Stability and change in American value priorities. American Psychologist, 44(5), pp. 775-784.

21. Rottier, A. (October 2001). Generation 2001: Loyalty and values - Generation X and work. Workforce. Retrieved July 29, 2008 from http://findarticles.com/p/articles/mi_mOFXS/is_10_80/ai_7935245?tag=rbxcra.2.a.3

22. Strauss, W. and Howe, N. (1997). The Fourth Turning: What the Cycles of History Tell Us Abut America's Next Rendezvous with Destiny. New York: Broadway Books.

23. Streeter, B. (December 2007). Welcome to the new workplace. ABA Banking Journal, 99(2), 7, 6 pages.

24. Trunk, P. (2007). What Generation Y really wants. Time. Retrieved May 20, 2008 from http://www.time.com/time/magazine/article/0,9171,1640395,00.html.

25. Wallace, J. (April, 2001). After X comes Y - echo boom generation enters workforce. HRMagazine. Retrieved July 29, 2008 from http://findarticles.com/p/articles/mi_m3495/is_46_ai_73848314

26. Weil, N. (2008). Welcome to the generation wars: As Boomer bosses relinquish the reins of leadership to Generation $\mathrm{X}$ both are worrying about Generation Y. For the good of the enterprise, everyone needs to do a better job of getting along. CIO, 21(8).

27. Yeaton, K. (April 2008). Recruiting and managing the 'why?' generation: Gen Y. The CPA Journal, 78(4) 68,5 pages. 
NOTES 